\title{
Edwin Seroussi, Ruinas sonoras de la modernidad: la canción popular sefardí en la era post-tradicional, traducción y edición de Susana Asensio Llamas, Madrid, Consejo Superior de Investigaciones Científicas, 2019, $160 \mathrm{pp}$.
}

Por razones que no es sencillo dilucidar, las canciones o kantikas (etiquetas simplificadoras que, aunque sea ese un detalle que a sus consumidores no les importa gran cosa, pueden englobar igual canciones legítimas que romances o coplas o himnos) de los judíos sefardíes del Mediterráneo oriental (mucho más que de los judíos sefardíes de la zona del Estrecho: tampoco se conocen muy bien las causas de ese favor y de ese disfavor) llevan mucho tiempo gozando, en España, en Israel, en Francia, en los Estados Unidos y, en definitiva, en el mundo global, del favor de un público casi masivo. Sus entusiastas suelen asumir, sin más, la identificación más o menos idealizada, incluso romántica, de tales canciones o kantikas con la memoria y con el alma o el espíritu de un pueblo que se las arregló para encontrar, entre exilios, amarguras y (algunos siguen diciendo) llaves de las añoradas casas de Toledo, momentos para cantar el amor, el desamor, el arrullo de los niños, los trabajos del día a día, la despedida de los muertos, las fiestas domésticas y comunitarias. Un público, en fin, en el que hay muchos sefardíes y en el que hay muchos que no lo son y que no tienen conocimiento de ningún otro aspecto de la cultura sefardí.

Es obvio, y más aún después de la lectura de este libro, que tras esa universal popularidad han estado moviéndose los hilos, en ocasiones concertados, de poderosos intereses identitarios, elevados a veces hasta a razón política, y de hábiles estrategias de mercadotecnia, a los que el autor asocia, en la p. 37, con unos cuantos nombres precursores:

Los editores y editoriales, que incluían empresas privadas como la de Alberto Hemsi -Édition de la Musique Orientale - en Alejandría (Egipto) u otras compañías más institucionales, tales como las influyentes publicaciones musicales posteriores a la guerra de la World Sephardic Federation (Federación Mundial Sefardí), apoyada con el dinero de las indemnizaciones, o las publicaciones de Isaac Levy en Jerusalén, favorecidas por el Gobierno de Israel a través de la intermediación del lobby sefardí.

El caso de las manipulaciones que se han hecho a costa de la copla (que no canción o kantika, aunque por tales las tenga el público menos conocedor) sefardí de $E l$ nacimiento y la vocación de Abraham es paradigmático de la decadencia progresiva («ruinización», llega a escribir Seroussi) que se ha ido cebando con este repertorio cultural. Ahorro los iluminadores párrafos preliminares acerca de sus primeros y rocambolescos migraciones y refritos, y selecciono unos pocos de los hallazgos que, en la p. 115 , nos comunica el autor:

En 1958, Léon Algazi reproduce nuestra canción en su influyente antología a partir de la partitura de Simoni. Esta reproducción canonizó la canción en esta versión, pero sin el 
acompañamiento de piano. A partir de aquí la antología de Algazi se convierte en una fuente principal para el renacimiento moderno de esta canción ladina (y de muchas otras) como música popular dentro de la industria musical. Tan pronto como 1963, el jazán Raphael Elnadav registra en Nueva York Cuando el rey Nimrod, en la versión publicada por Algazi. El cantante israelí Yehoram Gaon le sigue poco tiempo después, registrando en 1969 una versión comercial definitiva con arreglos orquestales, también basada en la versión de la antología de Algazi. A través de esta exitosa producción, la canción se convierte en un éxito internacional inmediato, imitado posteriormente en un sinnúmero de grabaciones comerciales realizadas y comercializadas dentro y fuera de Israel. La abrumadoramente rápida popularidad en todo el mundo de El nacimiento y la vocación de Abraham fue acompañada, más que en el caso de cualquier otra canción sefardí, por una súbita adquisición del aura de antigüedad ibérica. Como un ejemplo más de los incontables textos sobre nuestra canción elaborados por sus intérpretes comerciales, y disponibles en programas de concierto y cuadernillos de grabaciones, elegimos la siguiente cita, por ser representativa. Aparece en el CD Romances Judéo-espagnoles: Sefaradic [sic] romances from Spain, de la soprano Dominique Thibaudat y el Ensemble Lyrique Ibérique, uno más de la plétora de producciones comerciales registradas por conjuntos ad hoc en 1992, annus mirabilis para los intérpretes de música sefardí.

Del extravagante texto en francés del malhadado programa de mano salvaré solo una de sus frases más disparatadas, según está traducida en la p. 116 del libro de Seroussi: «el texto es contemporáneo de la escuela de Alfonso X el Sabio, alrededor de 1245-1280, en Toledo, su melodía está influenciada por el zejel a/a/a/b y la canción romanceada: Cantigas de Nuestra Señora)». Así, sin más.

Para compensar, añado unas palabras de una iluminadora nota a pie de página que figura en la p. 115, firmada por Seroussi: «la canción fue copiada de Algazi por Ch. Milner y P. Storm, Sephardische liederen en balladen, Romanzas, La Haya, Alberson, 1974, n. ${ }^{\circ}$ 35, y de allí, por Manuel García Morante en sus 40 Canciones sefardíes: Voz y piano, Barcelona, 1983, n. ${ }^{\circ}$, en una cadena caracterizada por el deterioro constante del texto...)».

Mejor estas citas, aun a riesgo de que pequen de extensas, que cualquier disquisición mía acerca de los contenidos y los enfoques de este libro agudo, erudito, inconformista, iconoclasta incluso, que se sostiene sobre los pilares de un conocimiento inigualable del entramado cultural (y no solo del lírico-musical) sobre el que pone su lente; de una competencia teórica y metodológica que trasciende el reducto de lo etnomusicólogo y se maneja con facilidad pasmosa en los dominios de una historiografía, una antropología y una sociología que ha tenido que elaborar ad hoc para esta materia (porque no había ninguna bibliografía crítica y de conjunto anterior) el propio autor; y de una determinación insobornable de plantar cara a los tópicos, generalidades, deformaciones y mentiras que se han vertido sobre y que han afectado radicalmente a la producción, la transmisión y la recepción de la tradición (o de la seudo-tradición, casi siempre) lírico-musical sefardí. Se echa de ver, en fin, la larguísima maduración del volumen, pues la mayor parte de sus capítulos habían sido publicados años ha (o décadas ha) por el autor, que ha dedicado su ya larga vida a desarrollarlos, actualizarlos, pulirlos y organizar un encaje compacto y armonioso dentro de este libro.

Seroussi desarrolla su programa en varias secciones muy meditadas y perfiladas: el «Prefacio» y los capítulos I («Definición de las ruinas sonoras de la modernidad»), II («Excavando las ruinas sonoras: las modernas canciones populares judeoespañolas en contexto»), así como el conclusivo VIII ( «Un jardín de ruinas sonoras y la condición posttradicional») son los de máxima densidad teórica e ideológica: desentrañan el tortuoso 
devenir histórico de la construcción del canon-vulgata del cancionero sefardí, que tuvo atisbos en el siglo XIX y se extendió como una mancha de aceite en el XX; subrayan sus grandes hitos (comunidades, cantores, migraciones, copias, compilaciones, refundiciones, partituras, discos, espectáculos, agentes, intermediarios, estrategas); y elaboran una interpretación muy aguda, apoyada sobre una serie de referencias interdisciplinares que casi agotan el más escogido y actualizado elenco de críticos señeros de la etnomusicología, la etnología y los llamados Folklore studies de hoy. No pocos de los estudiosos y de los tratados a los que apela el autor son, creo, citados por primera vez en una obra académica en español.

Aunque opino que ha obrado con sensatez Edwin Seroussi al ceñirse mayormente al marco de los Folklore studies, que ya es lo suficientemente pertinente y profuso, creo que algunos conceptos que han cuajado de manera poderosa en el ámbito de la historiografía, como el de la invención de la tradición (que fue acuñado en The Invention of Tradition, eds. Hobsbawm y Ranger), y en el ámbito de la sociología, como el de la patologización de la búsqueda de lo auténtico (pues el público consumidor de canciones sefardíes cree emotivamente que lo que compra es el acceso a una cultura auténtica, ingenua y ancestral), hubiesen servido muy bien a los propósitos de este libro. Al respecto podría verse el muy reciente ensayo de Carnevali (2018), que remite, obviamente, al tratado seminal de Guy Debord, La société du spectacle (1967). Por supuesto que hubiera sido también muy pertinente la apelación al ensayo celebérrimo de Walter Benjamin, La obra de arte en la época de su reproductibilidad técnica (1936), que aunque no está citado en la bibliografía, parece estar bien asumido en la trama profunda del libro de Seroussi. $\mathrm{O}$ a las grandes teorías acerca del imaginario colectivo alimentado por la industria cultural que ha elaborado Edgar Morin (francés cuyos padres eran sefardíes de Salónica, por cierto). Eso por citar solo algunos clásicos. Hoy, los estudios sobre las culturas fake están conociendo una expansión incomparable.

Otro concepto que opino que podría ser relacionado ventajosamente con los procesos culturales que analiza el autor de este ensayo es el de la museificación. Las canciones sefardíes son, para muchos de sus consumidores, algo así como las piezas de un museo livianamente exótico y fantasmal, que permiten imaginar una relación amable con un otro (el sefardí) que ya es nostalgia, y refugiarnos en la ilusión de una comunidad cultural regida por la armonía del conocimiento y el respeto entre ellos y nosotros. Los aficionados al museo de la canción sefardí tienen la ventaja, sobre los aficionados a los museos de momias egipcias o de dinosaurios antediluvianos, de que los sefardíes nos pillan más cerca y cantan mejor. Bensa (2016: 131) ha escrito estas palabras certeras. Cámbiese la palabra «museo» por la perífrasis «espectáculo lírico-musical sefardí», y la palabra «salvaje» por la palabra «sefardí», y el efecto será significativo:

En el museo la identidad se adhiere al pasado. Nada bueno podría venir del presente ni del futuro, los cuales, lejos de los orígenes, solo pueden ofrecer una imagen degradada de la humanidad original. Según el adagio de los conservadores, «todo lo antiguo es mejor», de manera que nada que sea auténtico puede ser reciente. De este modo, la experiencia estética que propone el museo consiste en un encuentro regresivo con lo arcaico. La escena primitiva se desarrolla en esos desvanes del psiquismo que vendrían a ser los museos etnográficos, atestados de objetos abandonados por los salvajes, esos grandes niños de la humanidad.

El capítulo III («De España al Mediterráneo oriental, ida y vuelta») es un estudio de caso centrado en la canción que suele ser conocida por su íncipit «A la una nací yo» $\mathrm{O}$ 
por su título convencional, Las horas de la vida. Sus genes proceden, por cierto, de la tradición oral española, en la que todavía hay quien la recuerda. Este capítulo es, posiblemente, el núcleo del libro, la sección más comprometida, la que con mayor despliegue de erudición y pericia desvela el enredo de las versiones y de las copias cada vez peor clonadas, la que acuña una metodología que servirá para los capítulos siguientes y la que llega a conclusiones más demoledoras: téngase en cuenta que su último epígrafe lleva el título, bien significativo, de «La ruinización de $A$ la una». Los demás epígrafes del capítulo tienden a remarcar los hitos cronológicos y topográficos que han ido marcando el paso de las canciones sefardíes en su camino hacia el espectáculo global: «Las canciones tradicionales sefardíes y el concepto de nación», «Las canciones ladinas a finales del franquismo», «Una juglar sefardí en Nueva York en 1958», «El ruiseñor oriental: Haim Effendi», «Tema y variaciones: Ginebra 1920, París 1937, Sofía 1972», «Regreso al futuro: Brooklyn, Nueva York, ca. 1961», «1972: un estudioso sefardí en Jerusalén», «La era de la reproducción mecánica». Algunos de sus párrafos (este es de la p. 61) son realmente antológicos:

Entre los visitantes más misteriosos en la última década de las ruinas de A la una yo nací (la forma en la que es más comúnmente nombrada y presentada al público hoy Las horas de la vida), se pueden mencionar Bang Jun-Seok y Jo Yeong-Wook. Estos dos compositores de bandas sonoras surcoreanos incluyen una sombría versión instrumental de la canción, quizás inspirada por la fantasía instrumental hiperdramática de «A la una» de Jordi Savall, aparecida en su CD doble de 1999, Diáspora Sefardí, interpretada por Hesperión XXI, en la banda sonora de la película de Park Chan-Wook Joint Security Area (2000). Centrada en la investigación de un tiroteo letal dentro de la zona desmilitarizada que separa Corea del Norte y del Sur, esta película es considerada como una de las películas coreanas más importantes de la historia.

Los demás capítulos centrales del libro vuelven a configurarse como muy solventes y justificados estudios de casos: el IV analiza la canción seriada, que era cantada en las bodas, de Las prendas de la novia; el V examina El hermano infame, que procede de un tardío pliego de cordel que anduvo muy oralizado por España hasta bien entrado el siglo XX (todavía queda algún residuo en el XXI); el VI se centra en la copla de $E l$ nacimiento y la vocación de Abraham; y el VII en el Bendigamos, una oración para la mesa, de uso doméstico, que ha seguido un itinerario fascinante en el ambiente sefardí. Todos estos capítulos comparten erudición, agudeza, espíritu crítico y un alto estilo literario.

El libro lleva un prólogo agudo y profundo del antropólogo Luis Díaz Viana: «Canciones para el futuro incierto. Del derrumbe de un mundo a las comunidades imaginadas». Ha sido traducido, con solvencia y ductilidad estilística que van muchísimo más allá de lo que es habitual, por la etnomusicóloga Susana Asensio Llamas. Y está adornado de un mérito adicional: hace el número veinte de la benemérita colección $D e$ acá y de allá. Fuentes etnográficas, del CSIC, que no cesa en su empeño de seguir enriqueciendo, con títulos de valor impagable, la bibliografía antropológica e históricocultural de que disponemos en nuestra lengua. 


\section{BIBLIOGRAFÍA CITADA}

BENSA, Alban (2016): El fin del exotismo: ensayos de antropología crítica, trad. Daniel Rudy Hiller, Zamora, Michoacán: El Colegio de Michoacán-Secretaría de Cultura.

CARnevali, Barbara (2018) : «Nostalgie pour l'authentique: Guy Debord et l'approche pathologique du spectacle», La forme spectacle, eds. Emmanuel Pedler y Jacques Cheyronnaud, París: Éditions de l'EHESS, pp. 87-101.

HoBSBAwm Eric y RANGER, Terence (eds.) (1983): The Invention of Tradition, Cambridge, Cambridge University Press.

José Manuel Pedrosa

(Universidad de Alcalá)

9 